FINANCIAL LIBERALIZATION AND ECONOMIC GROWTH IN TURKEY: A REEXAMINATION

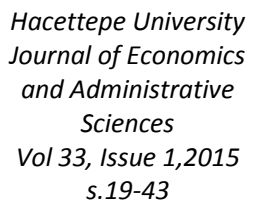

\author{
Gülenay Baş DİNAR \\ Assist. Proff., Abant İzzet Baysal \\ University \\ Department of Economics \\ gulenaybas@ibu.edu.tr

\section{Başak Çakar DALGIÇ} \\ Ph.D. Instructor, Hacettepe University \\ Department of Public Finance \\ basakcakar@hacettepe.edu.tr
}

\section{Pelin Varol İYIDOĞAN}

Assistant Professor, Hacettepe

University

Department of Public Finance

pelinv@hacettepe.edu.tr bstract: There is a wide empirical and
theoretical literature on the causal
relationship between financial liberalization and economic growth. The background of the issue is based on the McKinnon and Shaw hypothesis which emphasize that financial liberalization leads to economic growth via high saving and investment rates together with the technological improvements. While some empirical studies support McKinnon and Shaw hypothesis some others find contradictory evidence. In this context, utilizing recent data we investigate the relationship between financial liberalization and economic growth for Turkey over the period 1998-2012. Considering the structural breaks in the analysis period we first employ Zivot-Andrews unit root test and Gregory-Hansen cointegration analysis. Next we examine the causality relationship by means of Toda-Yamamoto methodology. Our main findings are; (i) there is a long run interaction between financial liberalization and economic growth, (ii) there is evidence of the causality running from economic growth to financial liberalization.

Keywords: Financial liberalization, growth, structural break, cointegration, causality. 
DOI: 10.17065/huiibf.75983

\title{
TÜRKIYY'DE FINNANSAL
}

\section{LİBERALİZASYON VE}

EKONOMIKK BÜYÜME:

\author{
Hacettepe Üniversitesi \\ iktisadi ve Idari Bilimler \\ Fakültesi Dergisi \\ Cilt 33, Sayı 1, 2015 \\ s. $19-43$
}

\section{YENİ BİR DEĞERLENDİRME}

\author{
Gülenay Baş DİNAR \\ Yrd.Doç.Dr. Abant İzzet Baysal \\ Universitesi \\ İktisadi ve İdari Bilimler Fakültesi \\ Ekonomi Bölümü \\ gulenaybas@ibu.edu.tr

\section{Başak Çakar DALGIÇ \\ Yrd.Doç.Dr., Hacettepe Universitesi \\ İktisadi ve İdari Bilimler Fakültesi \\ Maliye Bölümü \\ basakcakar@hacettepe.edu.tr}

\section{Pelin Varol İYİDOĞAN} \\ Yrd.Doç.Dr., Hacettepe Universitesi \\ İktisadi ve İdari Bilimler Fakültesi \\ Maliye Bölümü \\ pelinv@ hacettepe.edu.t
}

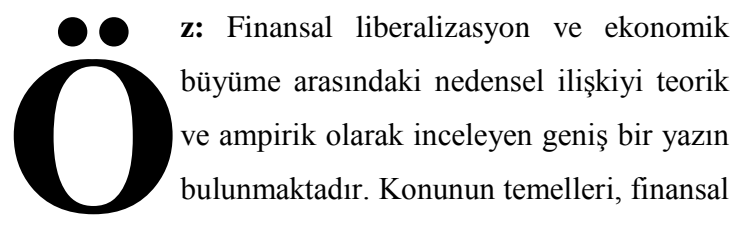
liberalizasyonun yüksek tasarruf ve yatırım oranlarının yanısıra teknolojik gelişmeler aracılığıyla ekonomik büyümeye yol açtığını vurgulayan McKinnon Shaw hipotezine dayanmaktadır. Ampirik çalışmaların bir kısmı McKinnon Shaw hipotezini desteklerken bazıları ise karşıt yönde sonuçlara ulaşmışlardır. Bu çerçevede, çalı̧̧mada Türkiye için 1998-2012 dönemine ait güncel verilerle finansal liberalizasyon ve ekonomik büyüme arasındaki ilișki incelenmektedir. Analiz dönemi içerisindeki olası yapısal kırılmalar dikkate alınarak öncelikle Zivot-Andrews birim kök testi ve GregoryHansen eşbütünleşme analizi uygulanmaktadır. Daha sonra ilgili değişkenler arasındaki nedensellik ilişkisi Toda-Yamamoto yöntemiyle incelenmektedir. Çalışmanın temel bulguları (i) Türkiye ekonomisinde finansal liberalizasyon ve ekonomik büyüme arasında uzun dönemli bir ilişkinin bulunduğu (ii) Nedensellik ilişkisinin ekonomik büyümeden finansal liberalizasyona doğru gerçekleştiği şeklindedir.

Anahtar Sözcükler: Finansal liberalizasyon, büyüme, yapısal kırılma, eşbütünleşme, nedensellik. 


\section{INTRODUCTION}

In 1980's, most countries have integrated into the global world economy together with financial liberalization process. As a consequence, important changes came into being in the financial systems of both developed and developing countries. In line with these developments, economic changes which were created by the financial liberalization attempts became an issue which has been researched intensively. In this context, many studies analysing the relationship between financial liberalization and economic growth have been conducted arguing that financial liberalization has a positive, negative or no impact on economic growth. Moreover, the direction of the causal relationship between financial liberalization and economic growth has also been studied. Besides the literature which asserts that the causal relationship is from financial liberalization to economic growth, some studies suggest that the demand for credits aroused from economic growth also leads to financial development and financial liberalization.

The approaches claiming that there is a positive interaction between financial liberalization and economic growth, explain the regarding relationship especially through neoliberal arguments. The foundations of the mentioned neoliberal arguments was laid with the studies of McKinnon (1973) and Shaw (1973) asserting that financial markets are kept under pressure in the developing countries. As a result of this financial pressure in these countries, the level of savings, thus the investment level is very low which lead to a decline in economic growth (Baş-Dinar, 2013).

McKinnon and Shaw suggest that developing countries should liberalize the financial markets via economic reforms so as to eliminate the vicious circle of low interest rate and growth rates. Accordingly, the positive impact of financial liberalization on economic growth is not limited with the rise in national savings. In that, enabling competitive financial markets, financial liberalization contributes to product range, service quality and technological improvements. Moreover, with 
DINAR, DALGIÇ, IYIIDOĞAN | Financial Liberalization and Economic Growth in Turkey: ...

financial liberalization, legal and required reserve ratio will be kept at a low level, which will enable banking sector to perform financial intermediation function effectively by decreasing the cost of fund resources. Furthermore, the finance of the credit deficits via financial liberalization will prevent the existence of unorganized markets in the developing countries, which will contribute to the development of financial system (McKinnon, 1973: 117; Gurley, Shaw, 1955; 1967; Fry, 1995).

In summary, financial liberalization can increase economic growth through many channels within the framework of McKinnon and Shaw hypothesis. In the regarding literature, these channels are divided into two groups as direct and indirect channels. Direct channels that determine economic growth directly can be summarized as the rise in national savings, the contribution to financial sector (Gurley, Shaw, 1955; 1967; Fry, 1995), decrease in the capital cost and transfer of technology from developed countries to the developing ones (Kang and Sawada, 2000; Singh, 2002). As for the indirect channels, they are the channels which affect economic growth indirectly, and can be listed as the increase of specialisation as a consequence of good risk management, development in macroeconomic and institutional policies regarding the competitive pressure or the disciplinary impact of liberalization and positive signals in the market indicating that the appropriate policies will be implemented (Fischer, 1997; Singh, 2002 and Yentürk, 2003; Prasad, et al., 2003).

After the financial liberalization processes in developing countries in 1980s, these countries experienced financial crises. As a result, this theory has been revisited and reconsidered. A special attention was paid to the problem of asymmetric information in financial markets. In this context, based on the studies of George Akerlof (1970), Michael Spence $(1973,1974)$ and Joseph Stiglitz and A. Weiss (1983, 1984), it was highlighted that the expected benefits of financial liberalization may not be achieved in the presence of asymmetric information in financial markets (Yoon, 1986). In these studies it is claimed that if there is an information asymmetry in financial markets between borrowers and lenders, problems as adverse selection and moral hazard will emerge. In the presence of such problems even if the financial liberalization 
is performed, the distribution of loans can not be realized efficiently (Yoon, 1986: 191). Furthermore, the existence of well-functioning capital markets is seen as a necessary condition for the success of financial liberalization.

Within this framework, our study aims to make an assessment of the possible relationships between financial liberalization and economic growth within the scope of the related literature and empirically analyze the causality relationship between the two variables in question for Turkey by using the quarter data over the period 1998-2012. In the previous studies about Turkey, the relationship between financial liberalization and economic growth does not support the McKinnon-Shaw Hypothesis. For instance, Kar and Pentecos (2001) reports a one way relationship from the economic growth to financial development. Using data for the period between 1980 and 2007, Hepsağ (2007) finds that the increase in interest rates after financial liberalization led to increase the savings and the loanable funds, but the increase in loanable funds did not lead to positive effect on real investments. In the study of Yapraklı (2007) finds a negative relationship between financial openness and GDP growth over the period 1990-2006. Yapraklı cannot find a causality relationship from financial liberalization to economic growth as predicted by the Mc Kinnon-Shaw Hypothesis.

In this study, first of all, stationarity of the series utilized is tested by means of Zivot-Andrews unit root test, in which structural breaks are considered, and then the long-run relationship between variables is examined through Gregory-Hansen cointegration analysis. Finally, Toda Yamamoto test which is independent of stationarity and cointegration properties of the series is applied. Our findings are checked via Lee and Strazizich (2003) unit root and Hatemi-J (2008) co-integration tests for two structural breaks together with Granger causality test based on error correction models. The results are found to be robust under alternative testing procedures. 
DINAR, DALGIÇ, IYIIDOĞAN | Financial Liberalization and Economic Growth in Turkey: ...

The remainder of the paper is organized as follows. Section 2 presents a brief review of the related literature. Section 3 discusses the methodology and empirical results. Section 4 concludes.

\section{1. . REVIEW OF LITERATURE}

Studies analyzing the impact of financial liberalization on economic growth yield three main results as the absence of any effect, positive and negative effects. On the other hand, the direction of causality between financial liberalization and economic growth has also been extensively discussed. In the related literature, studies which assert that there is a positive relationship between financial liberalization and economic growth, explain the relationship in question through the above-mentioned direct and indirect channels. In these studies which support Mc Kinnon and Shaw hypothesis, it is argued that financial liberalization contributes to the economic growth by leading to financial development and making the intermediary activities effective. These studies have been conducted based on the presumption that financial liberalization leads to financial growth (Ağır, 2010: 8).

In the studies handling the relationship between financial development and economic growth, the prominence is given to the financial system's function which leads the intermediation activities between savings and investments to become more effective. One of the early studies which stress the importance of financial intermediation services for economic growth was made by Goldsmith (1969). Goldsmith claims that the development of financial intermediation services will contribute to economic growth by increasing capital efficiency. The studies made by King, Levine (1993); Rajan, Zingales (1998); Levine, Zervos (1998) also corroborate the Goldsmith (1969).

The studies mentioned above directly handle the relationship between financial development and economic growth. There are also studies discussing that financial liberalization makes contribution to economic growth by leading to financial development (Kang, Sawada, 2000; Levine, 2001; Galindo, Schiantarelli, Weiss, 2005; 
Klein, Olivei, 2008). In these studies, it is asserted that financial liberalization will accelerate economic growth through a decline in intermediation costs by leading to financial development on one hand and an increase in efficiency by loosening the borrowing constraints on the other hand.

Another strand of the literature which analyze the relationship between financial liberalization and economic growth handles the issue with regards to the impact of financial liberalization on saving and investment decisions (Hermes, 1996; Bonfioli, 2005; Shresta, Chowdhury, 2007). The results of these studies confirm the McKinnon Show hypothesis which argues that the financial liberalization will increase savings and investments.

Apart from the above-mentioned studies, there are also studies that stress on indirect channels. In their studies, Batiz (2001), Bekaert, Harvey and Lundblad (2005) and Klein (2005) obtain evidence on the fact that countries that have better legal systems and institutions will record higher growth rates as a result of financial liberalization.

In another strand of the literature proposing a positive relationship between financial liberalization and economic growth, the impact of financial liberalization on economic growth and the destabilising impact of financial liberalization on macroeconomic growth are compared. In these studies, although it is accepted that the economies will be more fragile and fluctuating as a result of financial liberalization, it is also argued that, in general, the positive impact of financial liberalization on economic growth will be higher than its impact leading destabilisation. In this context, in an empirical study of 60 countries over the period 1980-2000, Ranciere, Tornell and Westermann (2006) reached findings indicating that the positive impact of financial liberalization on growth exceeds its negative impact. Loayza and Ranciere (2006) had similar findings, but they suggested that the short period impact which is negative, will be more prevailing in fragile economies. Likewise, according to Lee and Shin (2008), in which the impact of financial liberalization on economic growth is tested in two ways called direct growth impact and indirect crisis impact, while financial liberalization 
DINAR, DALGIÇ, IYIIDOĞAN | Financial Liberalization and Economic Growth in Turkey: ...

leads to an increase of 0.92 percent in GDP in all samples, this rate is 0.99 percent in the countries which have crisis experiences. The study concludes that financial liberalization contributes to economic growth even in the economies that experienced crisis.

To sum up, in the studies suggesting a positive relationship between financial liberalization and economic growth, this relationship is mainly explained by financial liberalization's such benefits as paving the way for financial services and brokerage activities, increasing the savings and investments and developing the institutional and administrational infrastructure. In some of these studies although it is confirmed that financial liberalization increase fragility of economies, it is suggested that its positive impact on economic growth is larger.

Most of the studies suggesting that there is no relationship between financial liberalization and economic growth or there is a negative relationship between them explain this through the arguments of financial liberalization's destabilising effects especially for developing economics (Grabel, 1995; Stiglitz, 2000; Singh 2002). The results of these studies support the arguments that the short-term funds which flow into economies by financial liberalization will cause huge crises in the economies decreasing real investments. In their study in which the institutional and political determinants of capital controls are examined by using data regarding 20 OECD countries for the period between 1950 and 1989, Alesina, Grilli and Milesi-Ferretti (1993) obtained results corroborating the hypothesis asserting that capital controls will negatively affect economic growth. In line with these findings, Arestis and Demetriades (1997) also find that financial pressure will have negative impacts on financial development and so on economic growth.

In the study in which they used the data on 22 countries labelled as more financially integrated (MFI), and 33 less financially integrated (LFI) countries over the period 1980-2000, Prasad, Rogoff, Wei and Köse (2003) obtained results indicating that financial liberalization increases macroeconomic volatilities. In Arestis (2004, 2005), 
examining financial liberalization applications in countries such as Colombia, Uruguay and Venezuela in 1970s, Malaysia, Argentina, Brazil, Chilli in thelately 1970s, Turkey and Israel, Philippines, Indonesia in the early 1980s and in Thailand, Malaysia and South Korea, it is concluded that financial liberalization policies causes destabilisation in the economies.

In another strand of the literature which reject the positive relationship between financial liberalization and economic growth, the issue is analyzed as to whether financial liberalization will increase the investment and saving level as it was estimated by McKinnon and Shaw hypothesis. One of these studies was conducted by Greene and Villanueva (1991). In this study in which the determinants of private investment are explored by utilizing the data of 23 developing countries for the period between 19751987, it is indicated that an increase of a 1 percent in real interest rate would decrease private investment expenditures by 0.1 percent. Likewise, in Demetriades and Devereux (1992) which uses data from 69 least developed countries for the period between 19611990 , the liberalization of interest rates on investment was determined to be negative. In Hepsağ (2009), it is shown that the increase of interest rates as a result of financial liberalization policies have a positive impact on the amount of savings and loanable funds but that it does not have such impact of on real investments in Turkey over 19802007.

In one of the studies, which tests the relationship between financial liberalization and economic growth directly, using data on 54 countries for the period 1960-1971, Eatwell (1996) finds that the ratio of investment to GDP decreased and the GDP growth decreased approximately by 40 percent. Rodrik (1998) uses the data regarding 100 developing countries for the period 1979-1989, and could not find a positive relationship between the three indicators of financial liberalization (per capita GDP growth, investment share in GDP and inflation) and economic performance. Yaprakl1 (2007) which uses the data regarding Turkey for the period between 1990 and 2006 finds a negative relationship between outward financial openness and GDP growth. 
DİNAR, DALGIÇ, IYIDOĞAN | Financial Liberalization and Economic Growth in Turkey: ...

Accordingly, when the trade openness rate is constant, 1 unit increase in financial openness in Turkey causes the growth rate decrease by 0.50 units.

In conclusion, studies suggesting a negative relationship between financial liberalization and economic growth, explain this mainly by the arguments that financial liberalization causes financial instabilities and crises in economies. Based on the cases of countries which experienced financial liberalization, it is determined that the instabilities and fluctuations occur in an economy as a result of financial liberalization and as a consequence, economic growth is affected negatively. Moreover, in some studies it is argued that, unlike what is asserted by McKinnon and Shaw hypothesis, the interest rates which increase after financial liberalization do not cause increases in saving and investment rates, and thus the resources for funding investments are not allocated efficiently.

In the above mentioned studies, while the direction of the causal relationship is from financial liberalization to economic growth, there are also studies suggesting that the direction of this relationship is from economic growth to financial liberalization. For example, by using data regarding 9 OECD countries and Chinese economy, Shan, Morris and Sun (2001) find a causal relationship from economic growth to financial development in some countries and for some other countries they obtain a bidirectional relationship between the variables in question. Similarly, Demetriades and Hussein (1996) find a unidirectional relationship from economic growth to financial development for some economies. Also in a study conducted for Turkey, Kar and Pentecos (2002) find a significant positive relationship from economic growth to financial development. In the next section we try to determine the direction of the relationship between financial liberalization and economic growth in Turkey utilizing a recent dataset.

\section{METHODOLOGY AND EMPIRICAL RESULTS}

In order to investigate the causal relationship between financial liberalization and growth in Turkey over the period 1998Q1-2012Q1 ${ }^{1}$, we built up three models. These 
models differ according to the proxies we use for financial deepening which are mainly the ratios of the domestic loans of private sector from the deposit money banks, BIST total traded value and M3 to GDP. The financial liberalization data is obtained from the Central Bank of Republic of Turkey (CBRT) Electronic Data Delivery System while the time series of expenditure-based GDP at current prices is collected from Turkish Statistical Institute. In all three models, as a proxy for economic growth, the real GDP per capita is generated by dividing GDP to midyear population estimations of Turkish Statistical Institute. Since all series have seasonality problem, the Census X12 procedure is used for the seasonal adjustment.

Since our analysis period includes November 2000, February 2001 financial crises and 2008 global crisis, the prospective structural breaks of these crises on the variables used in the study need to be taken into consideration. Disregarding these structural changes which occur in data, can lead to biased results in unit root tests as so in most of econometric methods.

As explained in Perron (1990), in case that there are structural breaks in time series, standard Dickey-Fuller (DF) test tends to accept null hypothesis of unit root. Therefore, Perron (1990) developed a unit root test with only one break in which the structural break is determined exegenously. Banarjee et al. (1992) and Christiano (1992) asserted that determining the break points exogenously can be considered as a type of data mining. Accordingly, a test strategy in which the structural break date is independent of data is not a consistent one as the break date is under observation. Zivot and Andrews (1992) developed a unit root test which determines the structural break endogeneously under the alternative hypothesis which enables an estimated break in trend function. Considering the periodical features of the series, Zivot and Andrews (1992) unit root test has been preferred for this study.

For the ZA unit root test, the following models are used. With sequential ADF test method, the test depends on different regression equation estimations for each of the prospective structural break points in the sample and it calculates t-statistics for the 
DİNAR, DALGIÇ, IYIDOĞAN | Financial Liberalization and Economic Growth in Turkey: ...

estimated parameters. At an unknown time point, in the autonomous and trend function curve, the trend with one-time break is tested with null hypothesis of unit root against the alternative hypothesis of stationarity. While Model A includes break at mean and Model B includes break in the trend, Model $\mathrm{C}$ includes the break to come into being both in trend and mean. In all three models, the null hypothesis is rejected if the coefficient $\alpha$ is statistically significant .

$$
\begin{aligned}
& \text { ModelA: } y_{t}=\mu+\alpha y_{t-1}+\beta_{t}+\theta_{1} D U_{t}(\lambda)+\sum_{j=1}^{k} d_{j} \Delta y_{t-j}+\varepsilon_{t} \\
& \text { ModelB: } y_{t}=\mu+\alpha y_{t-1}+\beta_{t}+\theta_{1} D T_{t}(\lambda)+\sum_{j=1}^{k} d_{j} \Delta y_{t-j}+\varepsilon_{t} \\
& \text { ModelC: } y_{t}=\mu+\alpha y_{t-1}+\beta_{t}+\theta_{1} D U_{t}(\lambda)+\gamma_{1} D T_{t}(\lambda)+\sum_{j=1}^{k} d_{j} \Delta y_{t-j}+\varepsilon_{t}(3)
\end{aligned}
$$

In Model (A), (B) and (C), $\varepsilon_{t}$ shows the normally distributed error term without autocorrelation. $T_{B}$ denotes the structural break point where $\lambda=T_{B} / T(\mathrm{t}=1, \ldots, \mathrm{T})$. In the above equations DU is the dummy variable defining the break at mean and DT is the dummy variable defining the break at trend:

$$
D U_{t}(\lambda)=\left\{\begin{array}{lr}
1 \text { ift }>T_{B} \\
0 & \text { o. } w
\end{array}\right.
$$

Table 1. Zivot Andrews Unit Root Tests ${ }^{2}$

\begin{tabular}{lllllll}
\hline \multicolumn{5}{c}{ Level } & \multicolumn{3}{c}{ 1st difference } \\
\hline Variables & Model A & Model B & Model C & Model A & Model B & Model C \\
\hline Credit & -3.398 & -3.662 & -4.136 & $-14.169 * * *$ & $-13.317 * * *$ & $-14.945^{* * *}$ \\
& $(2001 \mathrm{Q} 1)$ & $(2002 \mathrm{Q} 3)$ & $(2001 \mathrm{Q} 3)$ & & & \\
\multirow{2}{*}{ BIST } & -5.008 & $-4.541 * *$ & $-5.937 * * *$ & $-7.147 * * *$ & - & - \\
& $(2001 \mathrm{Q} 2)$ & $(2003 \mathrm{Q} 1)$ & $(2000 \mathrm{Q} 2)$ & & & \\
M3 & -3.294 & -3.871 & -3.880 & $-5.692 * * *$ & $-5.505 * * *$ & $-6.291^{* * *}$ \\
& $(2001 \mathrm{Q} 4)$ & $(2003 \mathrm{Q} 1)$ & $(2001 \mathrm{Q} 4)$ & & & \\
GDP & -2.760 & -1.950 & $-5.274 * *$ & $-21.803 * * *$ & $-21.429 * * *$ & - \\
& $(2008 \mathrm{Q} 3)$ & $(2009 \mathrm{Q} 3)$ & $(2009 \mathrm{Q} 1)$ & & & \\
\end{tabular}

Note: $* * * * * *$ and $*$ denote significance at $1 \%, 5 \%$ and $10 \%$ level respectively using the critical values from Table 4A in Zivot and Andrews (1992). The parantheses below the test statistics show the break points for the series.

Table 1 presents the ZA test statistics for the null hypothesis of a unit root in the GDP per capita and the three proxies we have chosen for the financial 
liberalization.According to all three models,for the Credit variable which represents domestic credit volume, the null hypothesis indicating the existence of a unit root at level can not be rejected. On the contrary, when the first difference of the relevant series is taken, they turn into stationary. When the variable BIST representing the ratio of Borsa İstanbul's total trading volume to GDP is used, although the null of unit root with a structural break at mean cannot be rejected, the series is stationary according to Model II and Model III. When the first difference of BIST serial is taken, the series becomes stationary according to Model I. Similarly, when M3 is analyzed as another financial indicator, it is integrated at order one in all of the three models above while GDP per capita which is the indicator of economic growth is integrated at order one according to Model I and Model II. Moreover, the structural break point estimates of the series refer to the breaks at the last quarter of 2001 and the first quarter of 2002 in the variables which represent financial liberalization. This result can be evaluated as the reflection of the 2001 crisis which affected Turkish economy deeply.

In case of the existence of structural breaks occurring in the time series during the analysis period, the impact of the potential structural changes need to be taken into consideration not only in unit root tests but also in cointegration tests which are used for testing the long term relationship between variables. The cointegration test developed by Gregory and Hansen (1996) (GH) considers a structural break which is endogeneously determined in cointegrating vector. Thus, GH test can be considered as an extension of ZA unit root test.

Gregory and Hansen (1996) considers three models allowing structural change in the cointegrating relationship, these models being specified and denoted as follows:

$$
\text { ModelC (Levelshift): } y_{t}=\mu_{0}+\mu_{1} D_{t}+\alpha_{1} x_{t}+\varepsilon_{t}
$$

Model C/T (Level shift with trend): $y_{t}=\mu_{0}+\mu_{1} D_{t}+\beta t+\alpha_{1} x_{t}+\varepsilon_{t}(6)$

ModelC /T(Regimeshift): $y_{t}=\mu_{0}+\mu_{1} D_{t}+\beta t+\alpha_{1} D_{t} x_{t}+\varepsilon_{t}$

Each of the above models therefore permits structural change via the dummy variable $D_{t}$ which is defined as 


$$
D_{t}=\left\{\begin{array}{lr}
1 \text { ift }>T_{B} \\
0 & \text { o. } W
\end{array}\right.
$$

with $T_{B}{ }^{3}$ denoting the point in the sample at which break occurs. The residuals obtained from the above cointegrating equations are then employed in the following DickeyFuller test to provide a modified Engle-Granger test which allows for structural change in the cointegrating relationship:

$$
\Delta \hat{\varepsilon}_{t}=(\rho-1) \hat{\varepsilon}_{t-1}+v_{t}(1)
$$

We build up three different cointegrating equations between economic growth and financial liberalization using the three different proxies of the financial liberalization. Thus, we test the three null hypotheses of a no long-run relationship between growth and financial liberalization. The results of the regarding GH tests are presented in Table 2. Most of the reported statistics are statistically significant at differing significance levels. Hence, allowing for a structural break in the cointegrating vector; there is strong evidence consistent across the three models used, in favour of a long run relationship between economic growth and financial liberalization.

Table 2. Gregory Hansen Cointegration Tests ${ }^{4}$

\begin{tabular}{llll}
\hline & ADF & $\mathbf{Z}_{\mathbf{t}}$ & $\mathbf{Z}_{\mathbf{a}}$ \\
\hline Credit-GDP & & & \\
Model C & $-3.70(2001 \mathrm{Q} 3)$ & $-6.54 * * *(2001 \mathrm{Q} 2)$ & $-48^{* *}(2001 \mathrm{Q} 2)$ \\
Model C/T & $-2.44(2001 \mathrm{Q} 3)$ & $-5.82 * * *(2002 \mathrm{Q} 3)$ & $-42.20(2002 \mathrm{Q} 3)$ \\
Model C/S & $-3.53(2001 \mathrm{Q} 3)$ & $-6.73 * * *(2004 \mathrm{Q} 1)$ & $-50.95 * *(2004 \mathrm{Q} 1)$ \\
BIST-GDP & & & \\
Model C & $-2.26(2005 \mathrm{Q} 2)$ & $-2.55(2001 \mathrm{Q} 3)$ & $-12.56(2001 \mathrm{Q})$ \\
Model C/T & $-2.50(2007 \mathrm{Q} 3)$ & $-5.31 * *(2001 \mathrm{Q} 3)$ & $-37.67(2001 \mathrm{Q} 3)$ \\
Model C/S & $-2.88(2000 \mathrm{Q} 4)$ & $-3.26(2000 \mathrm{Q} 4)$ & $-18.93(2000 \mathrm{Q} 4)$ \\
M3-GDP & & & \\
Model C & $-2.31(2002 \mathrm{Q} 4)$ & $-5.36 * * *(2001 \mathrm{Q} 4)$ & $-39.22 *(2001 \mathrm{Q} 4)$ \\
Model C/T & $-2.93(2002 \mathrm{Q} 3)$ & $-4.57(2001 \mathrm{Q} 4)$ & $-29.62(2001 \mathrm{Q} 4)$ \\
Model C/S & $-2.33(2002 \mathrm{Q} 4)$ & $-5.42 * *(2003 \mathrm{Q} 2)$ & $-39.48(2003 \mathrm{Q} 2)$ \\
\hline
\end{tabular}

Notes: $* * *, * *$ and $*$ denote significance at $1 \%, 5 \%$ and $10 \%$ level respectively using the asymptotic critical values from Table 1 in Gregory and Hansen (1996). The parantheses near the test statistics show the break points for the series. 
After employing Gregory-Hansen cointegration tests which refer to the existence of a long-term relationship between growth and financial liberalization, the short-run dynamics and the causality results are examined in this part of the study. For this purpose, the Granger causality test based on the estimated error correction models is performed (Appendix 1). The rejection of the null hypothesis implies the significance of the explanatory variables together with the error correction term, in other words the existence of causality. On the other hand, the significance of error correction term with negative sign indicates the short-run adjustments toward the long-run equilibrium. Moreover, for the sake of robustness, Toda and Yamamoto (1995) test which allows the causality relationship to be searched without the requirement of co-integration is applied. At the first stage of the TY test procedure, the maximum integration order of the variables in the system and the optimal lag length for the VAR model are determined. In the second stage, the estimated VAR model and causality relationships are analyzed.

We build up three different VAR models using the three different proxies of financial liberalization (Model I, Model II, Model III). The optimal lag length of VAR models are examined by AIC (Akaike Information Criterion), SC (Schwarz Criterion) ve HQ (Hannan-Quinn) criteriaand the appropriate lag length $(k)$ is determined to be 2 for all three models (Table 3). In addition, since taking the first difference of the variables make series stationary, the maximum integration order of the relevant variables (dmax) is 1 .

$$
\begin{gathered}
\text { ModelI: } G D P_{t}=\sum_{i=1}^{k+d \max } \alpha_{1 i} \text { Credit }_{t-i}+\sum_{i=1}^{k+d \max } \beta_{1 i} G D P_{t-i}+\varepsilon_{1 t} \\
\text { Credit } t=\sum_{i=1}^{k+d \max } \alpha_{2 i} G D P_{t-i}+\sum_{i=1}^{k+d m a x} \beta_{2 i} \text { Credit }_{t-i}+\varepsilon_{2 t} \\
\text { ModelII: GDP }=\sum_{i=1}^{k+d \max } \alpha_{1 i} I S E_{t-i}+\sum_{i=1}^{k+d \max } \beta_{1 i} G D P_{t-i}+\varepsilon_{1 t} \\
\text { ISE } E_{t}=\sum_{i=1}^{k+d \max } \alpha_{2 i} G D P_{t-i}+\sum_{i=1}^{k+d m a x} \beta_{2 i} I S E_{t-i}+\varepsilon_{2 t} \\
\text { ModelIII:GDP }=\sum_{i=1}^{k+d \max } \alpha_{1 i} M 3_{t-i}+\sum_{i=1}^{k+d \max } \beta_{1 i} G D P_{t-i}+\varepsilon_{1 t} \\
M 3_{t}=\sum_{i=1}^{k+d \max } \alpha_{2 i} G D P_{t-i}+\sum_{i=1}^{k+d \max } \beta_{2 i} M 3_{t-i}+\varepsilon_{2 t}
\end{gathered}
$$


DİNAR, DALGIÇ, IYIDOĞAN | Financial Liberalization and Economic Growth in Turkey: ...

Table 3. Optimal Lag Length forVAR Model

\begin{tabular}{|c|c|c|c|}
\hline Lag Length & $A I C$ & $S C$ & $H Q$ \\
\hline \multicolumn{4}{|l|}{ Model I } \\
\hline 0 & 16.19103 & 16.26825 & 16.22033 \\
\hline 1 & 7.118043 & 7.349694 & 7.205931 \\
\hline 2 & $6.741333 *$ & $7.127419 *$ & $6.887814 *$ \\
\hline 3 & 6.774937 & 7.315457 & 6.980009 \\
\hline 4 & 6.826487 & 7.521441 & 7.090151 \\
\hline 5 & 6.864567 & 7.713956 & 7.186824 \\
\hline 6 & 6.955252 & 7.959075 & 7.336101 \\
\hline 7 & 7.081134 & 8.239392 & 7.520576 \\
\hline 8 & 7.190942 & 8.503633 & 7.688975 \\
\hline \multicolumn{4}{|c|}{ Model II } \\
\hline 0 & 15.95673 & 16.03395 & 15.98603 \\
\hline 1 & 9.695530 & 9.927181 & 9.783418 \\
\hline 2 & 9.510645 & $9.896730 *$ & $9.657125^{*}$ \\
\hline 3 & $9.454222 *$ & 9.994742 & 9.659295 \\
\hline 4 & 9.510568 & 10.20552 & 9.774233 \\
\hline 5 & 9.557621 & 10.40701 & 9.879878 \\
\hline 6 & 9.692688 & 10.69651 & 10.07354 \\
\hline 7 & 9.698912 & 10.85717 & 10.13835 \\
\hline 8 & 9.700108 & 11.01280 & 10.19814 \\
\hline \multicolumn{4}{|c|}{ Model III } \\
\hline 0 & 15.38022 & 15.45743 & 15.40951 \\
\hline 1 & 7.194008 & 7.425659 & 7.281896 \\
\hline 2 & 6.802862 & $7.188947^{*}$ & $6.949342 *$ \\
\hline 3 & $6.777264 *$ & 7.317784 & 6.982336 \\
\hline 4 & 6.881630 & 7.576585 & 7.145295 \\
\hline 5 & 6.849675 & 7.699063 & 7.171931 \\
\hline 6 & 6.897292 & 7.901115 & 7.278141 \\
\hline 7 & 6.943353 & 8.101610 & 7.382794 \\
\hline 8 & 7.005746 & 8.318438 & 7.503780 \\
\hline
\end{tabular}

Note: "shows the optimallag length. 
The results of the F-tests regarding the TY procedure are given in Table 4. For all of the three VAR models (Model I, Model II, Model III) the non-causality from the financial liberalization variables to GDP variable can not be rejected. Whereas, the assumption of non-causality is rejected at $10 \%$ level from GDP to financial liberalization when Credit and BIST variables are used as proxies.These findings are consistent both with the results of some other studies analyzing the considered relationship in the literature (e.g. Demetriades and Hussein, 1996; Shan, Morris and Sun, 2001; Kar and Pentecos, 2002) and the Granger-causality test reported in Appendix 1. The contradictory result regarding the absence of causality from economic growth to financial liberalization indicator M3 is not surprising as being a broader proxy for financial sector than other proxies merely representing the financial properties of banking sector or stock market.

Table 4. Toda-Yamamoto Test Results

\begin{tabular}{ccc}
\hline Causality & F-Stat & p-value \\
\hline Financial liberalization $\Rightarrow$ Economic & \\
& & \\
Credit $\Rightarrow$ GDP & & \\
BIST $\Rightarrow$ GDP & 0.12810 & 0.9430 \\
M3 $\Rightarrow$ GDP & 0.33122 & 0.8028 \\
& 0.71818 & 05461 \\
Economic growth $\Rightarrow$ Financial liberalization & \\
GDP $\Rightarrow$ Credit & 2.42951 & 0.0770 \\
GDP $\Rightarrow$ BIST & 1.63021 & 0.0950 \\
GDP $\Rightarrow$ M3 & 1.19995 & 0.3201 \\
\hline
\end{tabular}

Therefore, the policy makers should also consider the prospective impacts of the economic policies which have either direct or indirect effects on the economic growth on financial liberalization. 


\section{CONCLUSION}

The research on the determinants of economic growth, that is one of the target variables of macroeconomic policies, constitutes the focus point of economic literature. The economic effects of globalisation which have been leading to the world economy since 1970s and the resultant financial liberalization implementations have been researched intensively. In this context, many studies have examined the economic growth as to whether the result of financial liberalization or its reason. On the other hand, when the fact that the economies with high growth rates also have developed financial systems is taken into consideration, determining the direction of the relationship between two variables in question empirically becomes important.

Accordingly, our study investigates the relationship between financial liberalization and economic growth in Turkish economy by using the quarter data over the period 1998-2012. In the analysis; the credits provided to private sector, BIST total traded volume, and M3 money-supply definition are considered as indicators of financial liberalization while per capita GDP represents economic growth. The economic crises and the resultant stabilisation measures in the mentioned period requires the possible structural breaks to be taken into consideration in the regarding variables. For this purpose, instead of conventional unit root and cointegration methods, the stationarity of the series and the long run relationship are analyzed by means of Zivot-Andrews and Gregory Hansen tests in which structural breaks are considered. Zivot-Andrews test indicates that structural breaks appeared for the proxy variables of financial liberalization in the last quarter of 2001 and first quarter of 2002 and that the series are integrated of first order after the break. As for Gregory-Hansen test results, they indicate the cointegration relation between economic growth and financial liberalization. In the final step of the analysis, the direction of the causal relationship between finance and growth is examined through Toda Yamamoto testing procedure. 
Two important results were obtained in the analysis, first of which indicates that economic growth causes financial liberalization. Therefore, fiscal and monetary policies which affect economic growth also make contribution to financial system's development accordant with market conditions. Especially the reflections of economic stability on growth with regard to "Transition to Strong Economic Program" which was implemented in the aftermath of 2001 crisis, led to innovations in financial system. As one of the major components of the financial sector, restructuring of the banking sector contributed substantially to the success of financial liberalization policies. As Akın et al. (2008) assert, the good side of the crisis was that it has provided regulators such like The Banking and Supervision Agency (BRSA). It has implemented serious measures regulating both state and private banks which finally aroused to increase in the efficiency of banking sector, thus a rise in capital inflows to the domestic financial markets. In accordance with the demand-following approach of Patrick (1966), economic growth made considerable contributions to financial liberalization through the rise in the demand of financial services together with the improvements in financial product range, organizational structure and financial prudential authorities in the considered period.

The other empirical finding of our study shows that causal relationship from financial liberalization to economic growth as asserted by McKinnon Shaw hypothesis was non-applicable in Turkish economy over the period in question. Different explanations can be made regarding the fact that the impacts of financial liberalization policies applied in the Turkish economy are not reflected in economic growth. First of all, the upward pressure of high public debt rates on the interest rates canalized savings to financial investment areas rather than real investments. Rising share of government bonds in the security portfolio of banks which were \%96.2 in 2011,\%97.2 in 2012 and $\% 96.3$ in 2013 renders the case of high public debt rates leading to increase in interest rates more evident. In this condition, financial markets failed to function as to fund the productive investments. Moreover, the public sector borrowing requirement which increased to high rates especially before 2001 crisis led to using an important share of savings for funding the fiscal deficits; and therefore, prevented savings from making 
DİNAR, DALGIÇ, IYIDOĞAN | Financial Liberalization and Economic Growth in Turkey: ...

contribution to economic growth through private investments. On the grounds of these reasons, although financial liberalization was not found to be a determinant for economic growth in Turkey, the steps which were taken for achieving the fiscal balance of public sector in the aftermath of 2001 crisis together with the instruments as mortgage and individual retirement system that have been included in financial system recently and existence of derivative markets can be effective in the future, and by this way, make McKinnon Shaw hypothesis valid.

\section{NOTLAR}

${ }^{1}$ Sample period is dictated by data availibility

${ }^{2}$ We also employ Lee and Strazicich (2003) unit root test under two structural breaks to double check the existence of unit root for the series in question. Consistent with ZA test, the series are found to be I(1) processes with regard to Model C.

${ }^{3}$ When determining the point at which to impose a break Gregory and Hansen (1996) suggest the use of a grid search procedure with all values in the central $70 \%$ of the sample being considered for $T_{B}$. For each of the models, the Dickey-Fuller test of (1) is estimated with the value employed as the resulting test statistic being the minimum value obtained for the t-ratio for $(\widehat{\rho-1})$.

${ }^{4}$ We also employ Hatemi-J (2008) cointegration test under two structural breaks which reveals consistent results with $\mathrm{G}-\mathrm{H}$ testing procedure supporting the evidence of long run relationship between economic growth and indicators of financial liberalization.

\section{REFERENCES}

Ağır, H. (2010) Türkiye'de Finansal Liberalizasyon ve Finansal Gelişsme İlişkisinin Ekonometrik Analizi, Ankara: BDDK Kitapları.

Akerlof, G. (1970) “The Market for 'Lemons': Quality, Uncertainty and The Market Mechanism”, The Quaterly Journal of Economics, 84(3), 488-500.

Akın, G.G., A.F. Aysan, L. Yıldıran (2008) "Transformation of the Turkish Financial Sector in the Aftermath of the 2001 Crisis”, MPRA Paper, No. 17803.

Alesina, A., V. Grilli, G.M. Milesi-Ferretti (1993) "The Political Economy of Capital Controls", NBER Working Paper Series, 4353.

Arestis, P. (2004) "Washington Consencus and Financial Liberalization", Journal of Post Keynesian Economics, 27(2), 251-271.

Arestis, P. (2005) "Financial Liberalization and The Relationship Between Finance and Growth",

CEPP Working Paper, 05/05. 
Banerjee, A., R. Lumsdaire, J.H. Stock (1992) "Recursive and Sequential Tests of the Unit-Root and Trend-Break Hypothesis: Theory and International Evidence, Journal of Business of Economic Statistics, 10(3).

Baş Dinar, G. (2013) "Finansal Liberalizasyon ve Ekonomik Büyüme: Literatür Çalışması", A.İ.B.Ü. - İ.İ.B.F. Ekonomik ve Sosyal Araştırmalar Dergisi, forthcoming.

Batiz, L.R. (2001) "International Financial Liberalization, Corruption, and Economic Growth", Review of International Economics, 9(4), 727-737.

Bekaert, G. and Harvey, C.R., Lundblad, C., (2005) "Does Financial Liberalization Spur Growth?", Journal of Financial Economics, 77, 3-56.

Bonfiglioli, A., (2005) “How Does Financial Liberalization affect Economic Growth?”,Institute for International Economic Studies Seminar Papers, 736.

Christiano L.J. (1992) "Searching for a Break in GNP", Journal of Business of Economic Statistics, 10(3).

Demetriades, P. and Devereux, M.P. (1992) "Investment and "Financial Repression" Theory and Evidence from 63 LDCs”, Keele University Working Paper in Economics, 92-116.

Demetriades, P. O. and Hussein K. A. (1996) "Does financial development cause economic growth? Time-series evidence from 16 countries", Journal of Development Economics, 51(2), 387-411

Dickey, D. and Fuller, W. (1979) "Distribution of the Estimation for Autoregressive Time Series with a Unit Root”, Journal of the American Statistical Association, 74, 427-431.

Eatwell, J., (1996) "International Capital Liberalization: The Impact on World Development", CEPA Working Paper Series, 1.

Engle, R.F. and Granger C.W.J. (1987) "Cointegration and Error Correction: Representation, Estimation and Testing”, Econometrica, 55(2), 251-276.

Fischer, S., (1997) "Capital Account Liberalization and the Role of the IMF", Asia and the IMF Conference, Hong Kong, China.

Fry, M.J., (1995) Money,Interest and Banking in Economic Development, Baltimore: John Hopkins University Press. 
DİNAR, DALGIÇ, IYIDOĞAN | Financial Liberalization and Economic Growth in Turkey: ...

Galindo, A., Schiantarell, F. and Weiss, A., (2005) "Does Financial Liberalization Improve the Allocation of Investment? Micro Evidence from Developing Countries”,Boston College Working Papers in Economics, 625.

Goldsmith, R. W. (1969) Financial Structure and Economic Development, New Haven: Yale University Press.

Grabel, I. (1995) "Assessing the Impact of Financial Liberalization on Stock Market Volatility in Selected Developing Countries", The Journal of Development Studies, 31(6), 903917.

Greene, J. and Villanueva, D. (1991) "Private Investment in Developing Countries: An Empirical Analysis", IMF Staff Papers, 38(1), 33-58.

Gregory, A. and Hansen, B. (1996) "Residual-based Tests for Cointegration in Models with Regime Shifts", Journal of Econometrics, 70, 99-126.

Gurley, J.G. and Shaw, E.S. (1955) "Financial Aspects of Economic Development", The American Economic Review, 45(4), 515-538.

Gurley, J.G. and Shaw, E.S. (1967) "Financial Structure and Economic Development”, Economic Development and Cultural Change, 15(3), 257-268.

Hatemi-J, A. (2008) "Tests for Cointegration with Two Unknown Regime Shifts with an Application to Financial Market Integration” Empirical Economics, 35, 497-505.

Hepsağ, A. (2009). "Finansal Liberalizasyon Politikalarının Geçerliliğinin McKinnon Tamamlayıcılık Hipotezi Çerçevesinde Sınanması: Türkiye Örneği”, BDDK Bankacılık ve Finansal Piyasalar, 3(1), 63-80.

Hermes, N., (1996) "Financial Reform and Financial İntermediation in Chile, 1983-1992", In Financial Development and Economic Growth: Theory and Experiences from Developing Countries, N.Hermes and R. Lensink (ed.), 310-336, London: Routledge.

Kang, S.Jb and Sawada, Y., (2000) "Financial Repression and External Openness in an Endogoneous Growth Model", Journal of International Trade and Economic Development, 9(4), 427-443.

Kar, M. and Pentecos, E. J. (2000) "Financial Development and Economic Growth in Turkey: Further Evidence on the Causality Issue”, Economic Research, 00-27, 1-21. 
King, R.G. and Levine, R., (1993) "Finance and Growth: Schumpeter Might be Right", Quarterly Journal of Economics, 108(3), 717-37.

Klein, M.W., (2005)“Capital Account Liberalization, Institutional Quality and Economic Growth: Theory and Evidence”, NBER Research Working Paper, 11112.

Klein, M.W.,and Olivei, G.P., (2008) "Capital Account Liberalization, Financial Depth and Economic Growth”, Journal of International Money and Finance, 27, 861-875.

Lee, I. and Shin, J.H. (2008) "Financial Liberalization, Crises, and Economic Growth", Asian Economic Papers, 7(1), 106-115.

Lee, J. and Strazicich, M.C. (2003) "Minimum Lagrange Multiplier Unit Root Test with Two Structural Breaks”, The Review of Economics and Statistics, 85(4), 1082-1089.

Levine, R. and Zervos, S., (1998) "Stock Market, Banks and Economic Growth", American Economic Review, 88, 537-58.

Levine, R., (2001) "International Financial Liberalization and Economic Growth", Review of International Economics, 9(4), 688-702.

Loayza, N. V. and Ranciere, R. (2006) "Financial Development, Financial Fragility, and Growth," Journal of Money, Credit and Banking, 38(4), 1051-1076.

McKinnon, R.I., (1973)Money and Capital in Economic Development, Washington D.C.: The Brookings Institution,

Patrick H.T. (1966) "Financial Development and Economic Growth in Underdeveloped Countries", Economic Development and Cultural Change, 14(2), 174-189.

Perron, P. (1990) “Testing for a Unit Root in a Time Series with a Changing Mean”, Journal of Business and Economic Statistics, 8(2).

Prasad, E.S., Rogoff, K., Wei, S.J. and Köse, A., (2003) "Effects of Financial Globalization on Developing Countries: Some Empirical Evidence", Economic and Political Weekly, 38(41), 4319-4330.

Rajan, R.G. and Zingales, L., (1998) "Financial Dependence and Growth", The American Economic Review, 88 (3), 559-586.

Ranciere, R., Tornell, A. and Westermann, F., (2006)“Decomposing The Effects of Financial Liberalization: Crises vs. Growth”, NBER Working Paper, 12806, 
DİNAR, DALGIÇ, IYIDOĞAN | Financial Liberalization and Economic Growth in Turkey: ...

Rodrik, D., (1998) “Who needs capital account convertibility?", Princeton Essays in International Finance, 207, 1-10.

Shan, J., Morris, A. and Sun, F. (2001) "Financial Development and Economic Growth: An Eggand-Chicken Problem”, Review of International Economics, 9(3), 443 - 454.

Shaw, E.S., (1973)Financial Deeping in Economic Development, Cambridge: Harvard University Press.

Shresta, M.B. and Chowdhury, K. (2007) "Testing Financial Liberalization Hypothesis with ARDL Modelling Approach", Applied Financial Economics, 17, 1529-1540.

Singh, A., (2002) Capital Account Liberalization, Free Long-Term Capital Flows, Financial Crises and Economic Development, ESRC Centre for Business Research, University of Cambridge Working Paper, 245.

Spence, M. (1973). “Job Market Signaling”, Ouarterly Journal of Economics, 87, 355-374.

Spence, M. (1974). Market Signaling,Cambridge: Harvard University Press.

Stiglitz J. and Weiss, A. (1981). "Credit Rationing in Markets With Imperfect Information", American Economic Review, 71, 393-410.

Stiglitz J. and Weiss, A. (1983). "Incentive Effects of Terminations: Applications to the Credit and Labor Markets”, American Economic Review, 73, 912-927.

Stiglitz, J., (2000). “Capital Market Liberalization, Economic Growth, and Instability”, World Development, 28(6), 1075-1086.

Toda, H.Y. and Yamamoto, T. (1995) "Statistical Inference in Vector Autoregressions with Possibly Integrated Processes", Journal of Econometrics, 66(1-2), 225-250.

Yapraklı, S. (2007). “Ticari ve Finansal Dışa Açıklık İle Ekonomik Büyüme Arasındaki İlişki: Türkiye Üzerine Bir Uygulama”, Ekonometri ve İstatistik, 5.

Yentürk, N., (2003)Körlerin Yürüyüşü: Türkiye Ekonomisi ve 1990 Sonrası Krizler, İstanbul: Bilgi Üniversitesi Yayınları.

Yoon, J.C. (1986) "Inefficiences from Financial Liberalization in the Absence of WellFunctioning Equity Markets”, Journal of Money, Credit and Banking, 18(2), 191-199. 
Zivot, E. and Andrews, D. (1992) "Further Evidence on the Great Crash, the Oil Price Shock and the Unit Root Hypothesis", Journal of Business and Economic Statistics, 10, 251270 .

Appendix 1

Table 1.Lee and Strazicich (2003) Unit Root Test

\begin{tabular}{|c|c|c|c|c|}
\hline \multirow[b]{2}{*}{ Variables } & \multicolumn{2}{|c|}{ Level } & \multicolumn{2}{|c|}{ First difference } \\
\hline & Model A & Model C & Model A & Model C \\
\hline Credit & $\begin{array}{l}-1.7493 \\
(2003 Q 3-2005 Q 2)\end{array}$ & $\begin{array}{l}-5.9722 * * * \\
(2003 Q 2-2008 Q 3)\end{array}$ & $\begin{array}{l}-5.8490 * * * \\
\text { (2002Q1-2009Q2 }\end{array}$ & - \\
\hline BIST & $\begin{array}{l}-2.1601 \\
(2001 Q 1-2009 Q 2)\end{array}$ & $\begin{array}{l}-5.9335 * * * \\
(2000 Q 2-2001 Q 1)\end{array}$ & $\begin{array}{l}-6.5054 * * * \\
(2000 Q 4-2002 Q 3)\end{array}$ & - \\
\hline M3 & $\begin{array}{l}-3.0199 \\
(2001 Q 1-2006 Q 3)\end{array}$ & $\begin{array}{l}-4.7106 * * * \\
(2001 Q 4-2007 Q 4)\end{array}$ & $\begin{array}{l}-6.9659 * * * \\
(2002 Q 4-2007 Q 1)\end{array}$ & - \\
\hline GDP & $\begin{array}{l}-3.0917 \\
(2007 Q 1-2009 Q 3)\end{array}$ & $\begin{array}{l}-5.9592 * * * \\
(2001 Q 1-2006 Q 3)\end{array}$ & $\begin{array}{l}-7.1935 * * * \\
(2002 Q 4-2007 Q 1)\end{array}$ & - \\
\hline
\end{tabular}

Notes: $* * * * *$ and $*$ denote significance at $1 \%, 5 \%$ and $10 \%$ level respectively using the critical values from Lee and Strazicich (2003). The parantheses below the test statistics show the break points for the series.

Table 2. Hatemi-J (2008) Cointegration Test

\begin{tabular}{lll}
\hline & Modified ADF & Modified Philips \\
\hline Credit-GDP & $-5.772^{*}$ & $-7.122 * * *$ \\
& $(2001 \mathrm{Q} 1-2001 \mathrm{Q} 2)$ & $(2000 \mathrm{Q} 1-2000 \mathrm{Q} 3)$ \\
BIST-GDP & -4.109 & $-5.932 *$ \\
& $(2002 \mathrm{Q} 2-2005 \mathrm{Q} 2)$ & $(2001 \mathrm{Q} 3-2004 \mathrm{Q} 1)$ \\
M3-GDP & $-5.996^{*}$ & $-6.597 * *$ \\
& $(2002 \mathrm{Q} 2-2006 \mathrm{Q} 3)$ & $(2000 \mathrm{Q} 2-2000 \mathrm{Q} 3)$
\end{tabular}

Notes: $* * *, * *$ and $*$ denote significance at $1 \%, 5 \%$ and $10 \%$ level respectively using the critical values from Hatemi $-\mathbf{J}$ (2008). The parantheses below the test statistics show the break points for the series. 
DINAR, DALGIÇ, IYIIDOĞAN | Financial Liberalization and Economic Growth in Turkey: ...

Table 3..Granger Causality Test Results

\begin{tabular}{ccc}
\hline & $\begin{array}{c}\text { Error correction term } \\
(\mathrm{p} \text {-value })\end{array}$ & $\begin{array}{c}\text { Causality: Wald stat } \\
(\mathrm{p} \text {-value })\end{array}$ \\
\hline Financial liberalization $\Rightarrow$ Economic growth & $0.07822(0.9715)$ \\
Credit $\Rightarrow$ GDP & $-0.01279(0.9256)$ & $0.30820(0.8193)$ \\
$\mathrm{BIST} \Rightarrow$ GDP & $-0.00192(0.7676)$ & $0.78871(0.6041)$ \\
$\mathrm{M} 3 \Rightarrow$ GDP & $--0.00866(0.5681)$ & \\
Economic growth $\Rightarrow$ Financial liberalization & $2.37185(0.0849)$ \\
GDP $\Rightarrow$ Credit & $-0.03368(0.0912)$ & $4.70429(0.0057)$ \\
GDP $\Rightarrow$ BIST & $-0.43101(0.0012)$ & $1.8823(0.1849)$ \\
GDP $\Rightarrow$ M3 & $-0.05949(0.1058)$ & \\
\hline
\end{tabular}

